\title{
Welfare impact analysis of paddy harvester CLAAS30
}

D.N. BASAVARAJAPPA, A.M. MARUTESHA, RAMAPPA PATIL AND AKMAL PASHA

Received : 18.06.2014; Revised : 17.03.2015; Accepted : 27.03.2015

See end of the Paper for authors' affiliation

Correspondence to :

D.N. BASAVARAJAPPA AICRP-IFS Scheme, Agricultural Research Station, KATHALAGERE (KARNATAKA) INDIA Email : basavarajdn@rediffmail.com
- ABSTRACT : The present study assessed the potential of using paddy harvesters and its impact on timeliness, harvesting cost, crop yield, farm income and employment. The results indicated that CLAAS30 ensured rapid harvesting, reduced harvesting costs, minimised post harvest losses, raised income of farmers and assisted farmers in overcoming labour shortages during the peak harvesting period. The machine replaced labour by about 90 per cent, reduced the harvesting costs by Rs. 5500 per hectare and increased net return by around Rs. 35000/ha. Field conditions such as crop density, crop maturity, soil moisture condition, weed population, plot size, lodging and operators skills determined the efficiency of harvesting. The CLAAS30 harvested 10 acres per day. The CLAAS30 is impressive equipment, which reduced the cost of paddy production by about 25-30 per cent and reduced post harvest losses to a considerable extent. The present study implies a positive welfare impact. Negative effects are noticed on employment opportunities and also on the income of harvesting labourers. Although the CLAAS30 has gained greater acceptance among farmers, the price of the machine is around 23 lakhs; which tend to discourage them to invest on this technology.

- KEY WORDS : Peddy harvester, CLAAS 30, Welfare impact analysis

- HOW TO CITE THIS PAPER : Basavarajappa, D.N., Marutesha, A.M, Patil, Ramappa and Pasha, Akmal (2015). Welfare impact analysis of paddy harvester CLAAS30. Internat. J. Agric. Engg., 8(1) : 132-135. 